Огляди літератури, оригінальні дослідження, погляд на проблему, ювілеї

УДК 616.24-007.272-036.1:616.12-008.331.1-036.3:616-002

DOI 10.11603/1811-2471.2018.v0.i3.9346

\title{
ФАКТОРИ СЕРЦЕВО-СУДИННОГО РИЗИКУ ТА ПРОЯВИ ПЕРСИСТУЮЧОГО СИСТЕМНОГО ЗАПАЛЕННЯ У ХВОРИХ З КОМОРБДНІСТЮ ХРОНІЧНОГО ОБСТРУКТИВНОГО ЗАХВОРЮВАННЯ ЛЕГЕНЬ ТА АРТЕРІАЛЬНОЇ ГІПЕРТЕНЗІЇ
}

\author{
ФО. М. Коваленко, В. В. Родіонова \\ ДЗ «Дніпропетровська медична академія Міністерства охорони здоров'я України»
}

РЕзЮМЕ. Підвищення рівня персистуючого системного запалення, одним з важливих біомаркерів якого $\epsilon$ С-реактивний білок (СРБ), є фактором, що сприяє виникненню серйозних серцево-судинних подій як у хворих із серцево-судинною патологією, так і з хронічним обструктивним захворюванням легень (ХОЗЛ).

Мета - оцінити рівень сироваткового ультрачутливого С-реактивного білка (hsСРБ) та його зв'язок із факторами серцево-судинного ризику, активністю тромбоцитів у хворих з коморбідністю хронічного обструктивного захворювання легень (ХОЗЛ) та артеріальної гіпертензії (АГ).

Матеріал і методи. У дослідження увійшли 84 пацієнти в стабільному стані, I гр. склали 44 хворих на ХОЗЛ у поєднанні з АГ І-ІІ стадії, II гр. - 40 хворих з АГ І-ІІ стадії. Проведені оцінка клініко-анамнестичних даних, визначення офісного артеріального тиску (АТ), індексу маси тіла (IMT), статусу куріння та ступеня нікотинової залежності (Fagerstrom Test for Nicotine Dependence - FTND); високочутливе визначення концентрації сироваткового hsCРБ (ІФА), ліпідного профілю, ступеня адгезії, індукованої агрегації тромбоцитів (Тр) та фібриногену (ФГ), в I гр. - оцінка задишки за mMRS, частоти загострень протягом року, спірографія.

Результати. Рівень һsСРБ в I гр. був незалежний від віку, IMT, статусу куріння, ліпідного профілю, але мав зв'язок із збільшенням бронхообструкції та рівнем mMRS ( $<<0,05)$. При IMT $\leq 25 \mathrm{kr} / \mathrm{M}^{2}$ в I гр. був вище, ніж в II гр.

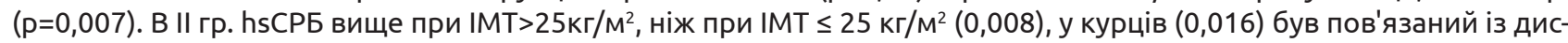
ліпідемією ( $<0,05)$. Індукована колагеном, тромбіном агрегація (Агр) в I гр. мала зворотний зв'язок, в II гр. індукована колагеном Агр - прямий кореляційний зв'язок із hsCРБ (p<0,05), але загальна адгезивна та індукована Агр активність Тр в I гр. була вище, ніж в II гр. У I гр. рівень фібриногену мав прямий кореляційний зв'язок із һsСРБ та зворотний - $О Ф \mathrm{~B}_{1}$.

Висновки. Підвищення рівня һsСРБ та ФГ у стабільних пацієнтів із ХОЗЛ, поєднаним з АГ, пов'язано із респіраторними порушеннями, при АГ - із збільшенням IMT, дисліпідемією, залежністю від куріння. Загальний протромботичий потенціал у хворих I гр. був вищим, ніж у II гр., особливо при курінні, що обумовлено підвищенням адгезивно-агрегаційної активності Тр, а також зростанням фібриногенемії із збільшенням рівня hsCPБ.

КЛючОВІ СЛОВА: ХОЗЛ; артеріальна гіпертензія; системне запалення; високочутливий С-реактивний білок; фактори серцево-судинного ризику; тромбоцитарна активність.

Вступ. Хронічне обструктивне захворювання легень (ХОЗЛ) - поширене захворювання, яке зазвичай діагностують у віці понад 40 років, що має високу коморбідність. На його перебіг впливають частота та тяжкість загострень і наявність супутніх захворювань [1]. Серцево-судинні захворювання (ССЗ) займають провідне місце в коморбідності при ХОЗЛ [2] та роблять значний внесок у формування летальності в цієї категорії хворих. ССЗ $є$ причиною смерті 13 \% хворих із тяжким та вкрай тяжким ступенем порушення зовнішнього дихання і майже третини (28 \%) з легким та середнім ступенями [3]. АГ - провідний фактор ризику IXC та цереброваскулярної патології, її виявляють у 40-60 \% хворих на ХОЗЛ [4].

У формуванні патологічних змін, що призводять до розвитку атеросклерозу та атеротромбозу, як морфологічного субстрату при переважній більшості ССЗ, ключову роль грають розвиток ендотеліальної дисфункції (ЕД) та активація тромбоцитарної ланки гемостазу $[5,6]$. Персистуюче системне запалення - один із основних факторів, що сприяють розвитку ЕД. Підвищення в плазмі рівня прозапальних цитокінів (ІЛ-6, ФНП-а, ІЛ-1 $\beta$, ІЛ-18, хемокіну ІЛ-8) [7] викликає нейтрофільномакрофагальну, тромбоцитарну активацію, підвищує експресію адгезивних молекул судинним ендотелієм, що обумовлює тромбоцитарну адгезію та агрегацію з подальшим тромбоутворенням $[5,6]$. Вплив на розвиток і підтримку процесу запалення при ХОЗЛ та ССЗ має ряд «спільних" цитокінів (ІЛ-6, ФНП-а, ІЛ-1а, ІЛ-1ß), що пов'язані із атерогенезом. Позалегенева транслокація прозапальних цитокінів при ХОЗЛ, насамперед ІЛ-6, обумовлює синтез у гепатоцитах гострофазових білків, одним з найкраще вивчених вважається СРБ. Закономірно, що його рівень значно підвищується при вираженій активності запалення, але наявність хронічної патології, навіть за умов відносної функціональної компенсації, обумовлює деякий рівень інтенсивності запалення. В останній час приділяється увага вивченню особливостей так званого персистуючого системного запалення низької інтенсивності. Із персистуючим системним запаленням та рівнем СРБ пов'язують підвищення смертності від всіх причин при ста- 
Огляди літератури, оригінальні дослідження, погляд на проблему, ювілеї

більному ХОЗЛ у хворих із легкими та середніми проявами захворювання [9]. За результатами досить великої кількості досліджень һsСРБ $є$ предиктором серйозних кардіоваскулярних подій [10]. На сьогодні взаємозв'язок із встановленими факторами серцево-судинного ризику не достатньо з'ясований, особливо при коморбідних станах.

Мета дослідження - оцінити рівень сироваткового ультрачутливого С-реактивного білка (hsCРБ) та його зв'язок із факторами серцево-судинного ризику, активністю тромбоцитів у хворих при коморбідності ХОЗЛ і АГ.

Матеріал і методи дослідження. В дослідження були включені 84 пацієнти. До I групи (гр.) увійшли 44 хворих на ХОЗЛ A - D з порушенням функції зовнішнього дихання II-IV ст. за GOLD у поєднанні з артеріальною гіпертензією I-ІІ стадій; до II групи - 40 хворих з артеріальною гіпертензією І-ІІ стадій. Обстежені пацієнти мали стабільний стан (відсутність загострення ХОЗЛ та зафіксованих гіпертонічних кризів щонайменше протягом 2 останніх місяців).

Дослідження проводили на тлі застосування пацієнтами обох груп стандартної базисної терапії згідно з рекомендаціями GOLD та Клінічними рекомендаціями з артеріальної гіпертензії Європейського товариства гіпертензії (ESH) та Європейського товариства кардіологів (ESC) 2013.

До дослідження не включали пацієнтів віком старше 80 років, з гострими серцево-судинними подіями в анамнезі, клінічно значущими порушеннями серцевого ритму, цукровим діабетом, злоякісними новоутвореннями, перенесеним протягом останнього року оперативним втручанням. Усі пацієнти, що були включені в дослідження, дали згоду на участь в ньому.

Усім пацієнтам були проведені оцінка клінікоанамнестичних даних з визначенням офісного артеріального тиску (АТ), індексу маси тіла (IMT), статусу куріння та оцінка ступеня нікотинової залежності (Fagerstrom Test for Nicotine Dependence FTND); визначення рівня сироваткового hsСРБ (твердофазовий імуноферментний аналіз («СРБ ІФА - БЕСТ високочутливий», Росія), загального холестерину (3X), ліпопротеїдів високої щільності
(лПВЩ), ліпопротеїдів низької щільності (ЛПнЩ), ліпопротеїдів дуже низької щільності (ЛПДНЩ), тригліцеридів (ТГ) з розрахунком коефіцієнта атерогенності (біохімічний аналізатор «Hoffmann-La Roche», Швейцарія), дослідження показників тромбоцитарного гемостазу: кількості тромбоцитів (Тр), ступеня адгезії (Адг) Тр, ступеня агрегації (Агр), їі швидкості та активності тромбоцитарного фактора фон Віллебрандта (Tp vWF) при індукції АДФ, колагеном та тромбіном агрегації (Агр) Тр та фібриногену (аналізатор "Солар» 2110, Білорусь). В I гр. хворих, із поєднанням ХОЗЛ та АГ, проведена оцінка тяжкості задишки (The Modified Medical Research Counsil Dyspnea Scale - (mMRS)), частоти загострень протягом року, спірографічних даних (об'єм форсованого видиху за 1 секунду (ОФВ $)_{1}$ ), форсованої життєвої ємності легень (ФЖЄЛ), їх співвідношення - ОФВ $/$ /ФЖЕЛ). Статистичну о6робку даних проводили з використанням програмного забезпечення Statistika 6.1 із визначенням середніх показників, медіани та квартилів (Ме [25 - 75]), критерію Манна - Уітні (U), коефіцієнта рангових кореляцій Спірмена (R). Статистична достовірність визначалася при рівні $p<0,05$, тенденція - при рівні $<<0,1$.

Результати й обговорення. УІ гр. були включені пацієнти із поєднанням ХОЗЛ та АГ із показ-

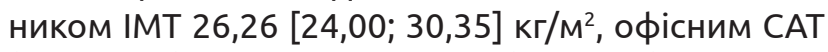
$(154,1 \pm 9,7)$ мм рт. ст. та ДАТ - $(94,3 \pm 8,1)$ мм рт. ст. Позитивний статус куріння на період дослідження мали 25 (57\%), пацієнтів курили у минулому 11 (25\%), заперечували в будь-який період $8(18 \%)$ хворих.

До II гр. увійшли 42 пацієнти з АГ з ІМТ 26,13 $[24,61 ; 29,20] \mathrm{kr} / \mathrm{M}^{2}$, офісним САТ $(157,2 \pm 10,3)$ мм рт. ст., ДАТ - $(96,5 \pm 7,7)$ мм рт. ст. Позитивний статус куріння мали 19 (45\%) хворих, курили в минулому 8 (19 \%), заперечували - 15 (36\%) пацієнтів. Ступінь нікотинової залежності був дещо вищим у пацієнтів I гр., ніж II гр., але без доведеної статистичної різниці $(p=0,293)$.

Таким чином, хворі обох груп за віком $(p=0,833)$, показником IMT $(p=0,878)$, показниками САТ $(p=0,572)$, ДАТ $(p=0,631)$ та ставлення до куріння були статистично однорідними (табл. 1).

Таблиця 1. Загальна характеристика пацієнтів, Включених у дослідження

\begin{tabular}{|c|c|c|c|c|c|c|c|}
\hline \multicolumn{2}{|c|}{ Група хворих } & $\begin{array}{c}\text { Вік, } \\
\text { роки }\end{array}$ & $\begin{array}{l}\text { IMT, } \\
\mathrm{Kr} / \mathrm{M}^{2} \\
\end{array}$ & $\begin{array}{c}\text { Нікот. залежн., } \\
\text { бали } \\
\end{array}$ & $\begin{array}{c}\text { САТ, } \\
\text { мм рт. ст. }\end{array}$ & $\begin{array}{c}\text { ДАТ, } \\
\text { мм рт. ст. }\end{array}$ & $\begin{array}{c}\text { hsCPБ, } \\
\text { Мг/л }\end{array}$ \\
\hline \multicolumn{2}{|c|}{ I-ХОЗЛ + АГ } & \multirow[t]{2}{*}{$57,1 \pm 8,3$} & \multirow{2}{*}{$\begin{array}{c}26,26 \\
{[24,00 ; 30,35]}\end{array}$} & \multirow{2}{*}{$\begin{array}{c}5,0 \\
{[0,0 ; 6,0]}\end{array}$} & \multirow[t]{2}{*}{$154,1 \pm 9,7$} & \multirow[t]{2}{*}{$94,3 \pm 8,1$} & \multirow{2}{*}{$\begin{array}{c}5,76 \\
{[2,55 ; 10,81]}\end{array}$} \\
\hline $4-35(79,5 \%)$ & ж-9(20,5\%) & & & & & & \\
\hline \multicolumn{2}{|c|}{$\mathrm{II}-\mathrm{A} \Gamma$} & \multirow[t]{2}{*}{$57,3 \pm 6,4$} & \multirow{2}{*}{$\begin{array}{c}26,13 \\
{[24,61 ; 29,20]}\end{array}$} & \multirow{2}{*}{$\begin{array}{c}2,57 \\
{[0,0 ; 5,0]}\end{array}$} & \multirow[t]{2}{*}{$157,2 \pm 10,3$} & \multirow[t]{2}{*}{$96,5 \pm 7,7$} & \multirow{2}{*}{$\begin{array}{c}3,67 \\
{[1,42 ; 8,97]} \\
\end{array}$} \\
\hline $4-31(74 \%)$ & ж-11(26\%) & & & & & & \\
\hline Рівень р * & & 0,833 & 0,878 & 0,293 & 0,572 & 0,631 & 0,166 \\
\hline
\end{tabular}

Примітка. * - критерій Манна - Уїтні (ч) при достовірності на рівні р<0,05. 
Огляди літератури, оригінальні дослідження, погляд на проблему, ювілеї

\section{Вплив вікових змін на рівень hsСРБ}

Вплив віку на рівень һsСРБ як в I гр. хворих $(r=+0,109, p=0,516)$, так і в II групі хворих $(r=+0,321$, $\mathrm{p}=0,145)$ виявлений не був.

\section{Зв'язок змін IMT з рівнем hsCPE}

У I гр. зміни IMT не впливали на фоновий рівень hsCРБ $(r=-0,105, p=0,529)$. Показник hsСРБ у хворих з IMT $\leq 25 \mathrm{kг} / \mathrm{M}^{2}(8,97[1,58 ; 11,73] \mathrm{Mг} /$ л) статистично не перевершував $(p=0,615)$ рівень, визначений у гіперстенічних пацієнтів цієї групи $(5,2$ $[2,55 ; 10,81] \mathrm{Mr} / л)$. Водночас hsСРБ у нормостенічних коморбідних хворих $(9,13[2,92 ; 27,79]$ мг/л) був значно вищим, ніж у нормостенічних хворих групи з АГ (2,4 [1,33; 3,67] мг/л), $p=0,007$.

В II гр. з підвищенням маси тіла рівень һsСРБ зростав $(r=+0,478, p=0,024)$ і в хворих з IMT>25 $\mathrm{kr} / \mathrm{M}^{2}$ $(8,56[4,79 ; 13,26]$ мг/л) був значно вищим, ніж 3 IMT $\leq 25 \mathrm{Kr} / \mathrm{M}^{2}(2,20[1,37 ; 3,67] \mathrm{Mr} / л), \mathrm{p}=0,008$. ріння

Зміни рівня hsСРБ залежно від статусу ку-

При поєднанні ХОЗЛ і АГ зв'язку між һsСРБ та рівнем нікотинової залежності не виявлено $(r=+0,097, p=0,563)$. Показники hsСРБ у коморбідних хворих із позитивним статусом куріння $(6,83$ [2,24; $10,81] \mathrm{mr} / л)$ та тих, які не курили $(5,41[2,55 ; 10,55] \mathrm{Mr} / л)$, не мали суттєвих відмінностей $(p=0,899)$. Водночас при негативному статусі куріння у хворих із поєднанням ХОЗЛ і АГ рівень һsСРБ $(5,41$ [2,55; $10,55]$ мг/л) був достовірно вищим $(p=0,044)$, ніж у некурців з АГ $(2,24[0,82 ; 4,79]$ мг/л). У курців з групи АГ рівень һsСРБ $(8,97[3,67 ; 14,89]$ мг/л) також був суттєво вищим ( $p=0,016)$, ніж у хворих цієї групи, які не курили $(2,24[0,82 ; 4,79]$ мг/л), при цьому показник hsСРБ зростав при підвищенні виразності нікотинової залежності $(r=+0,553, p=0,0075)$.

\section{Ліпідний профіль та иऽСРБ}

Показники ліпідного профілю хворих обох груп представлені в таблиці 2. В групі коморбідних хворих будь які статистично достовірні зміни рівня hsСРБ залежно від показників ліпідного спектра крові виявлені не були. Протилежна картина була виявлена в пацієнтів групи АГ, а саме: рівень hsСРБ збільшувався при зменшенні рівня ХС ЛПВЩ ( $(=-0,641, p=0,002)$, підвищенні ХС ЛПДНЩ $(r=+0,416, p=0,05)$ та відповідному підвищенні КА $(r=+0,425 p=0,049)$.

Таблиця 2. Показники ліпідного профілю сироватки крові у хворих з артеріальною гіпертензією та у хворих із поєднанням хронічного обструктивного захворювання легень та артеріальної гіпертензії

\begin{tabular}{|c|c|c|c|}
\hline Показник & ХОЗЛ+АГ & $\mathrm{A} \Gamma$ & Рівень P* $^{*}$ \\
\hline $3 \times C$ & $\begin{array}{c}4,55 \\
{[3,94 ; 5,21]}\end{array}$ & $\begin{array}{c}5,45 \\
{[4,41 ; 6,04]}\end{array}$ & 0,016 \\
\hline ХС лпВЩ & $\begin{array}{c}1,19 \\
{[1,05 ; 1,35]}\end{array}$ & $\begin{array}{c}1,08 \\
{[0,79 ; 1,29]}\end{array}$ & 0,131 \\
\hline ХС лпнЩ & $\begin{array}{c}2,75 \\
{[2,20 ; 3,15]}\end{array}$ & $\begin{array}{c}2,89 \\
{[2,13 ; 3,83]}\end{array}$ & 0,569 \\
\hline ХС ЛПдНЩ & $\begin{array}{c}0,50 \\
{[0,42 ; 0,82]}\end{array}$ & $\begin{array}{c}0,69 \\
{[0,47 ; 1,02]}\end{array}$ & 0,092 \\
\hline $\mathrm{T \Gamma}$ & $\begin{array}{c}1,11 \\
{[0,86 ; 1,48]}\end{array}$ & $\begin{array}{c}1,55 \\
{[1,04 ; 2,22]}\end{array}$ & 0,060 \\
\hline KA & $\begin{array}{c}2,83 \\
{[2,19 ; 3,35]}\end{array}$ & $\begin{array}{c}3,02 \\
{[2,57 ; 4,21]}\end{array}$ & 0,184 \\
\hline
\end{tabular}

Примітка. * - критерій Манна - Уїтні (u) при статистичній достовірності на рівні p<0,05, тенденції - при рівні р<0,10.

Влив особливостей перебігу ХОзл на рівень hsСРБ у коморбїних Хворих на ХОзЛ та АГ

Очікувано, що за відсутності статистично підтвердженого зв'язку фонового рівня һSСРБ із по- казниками IMT, статусу куріння та ліпідного профілю у коморбідних хворих, на відміну від хворих з ізольованою АГ, цей зв'язок був виявлений при аналізі особливостей ХОЗЛ (табл. 3).

Таблиця 3. Рівень hsСРБ та особливості перебігу хронічного обструктивного захворювання легень у хворих із поєднанням хронічного обструктивного захворювання легень та артеріальної гіпертензії

\begin{tabular}{|l|c|c|c|c|c|}
\hline \multicolumn{1}{|c|}{ Показник } & $\begin{array}{c}\mathrm{OФB}_{1} \\
\%\end{array}$ & $\begin{array}{c}\text { ФЖЭЛ, } \\
\%\end{array}$ & ОФВ $_{1} /$ ФЖЭЛ & $\begin{array}{c}\text { Рівень } \\
\text { mMRS }\end{array}$ & $\begin{array}{c}\text { Частота } \\
\text { загострень }\end{array}$ \\
\hline$\Gamma^{*}=$ & $-0,198$ & $+0,104$ & $-\mathbf{0 , 4 5 3}$ & $\mathbf{+ 0 , 4 4 3}$ & $+0,001$ \\
\hline $\mathrm{p}^{* *}=$ & 0,232 & 0,533 & $\mathbf{0 , 0 0 3}$ & $\mathbf{0 , 0 0 5}$ & 0,952 \\
\hline
\end{tabular}

Примітки: 1 - *значення коефіцієнта рангової кореляції Спірмена; 2. - ** статистично достовірні при рівні р<0,05.

Привертає увагу, що в курців I гр. рівні ОФВ $(55,2[48,5 ; 61,8] \%)$, ОФВ 1 /ФЖЄЛ $(0,58[0,45 ; 0,67])$ були вищими ( $p=0,04 ; 0,019)$, а частота загострень $(1,67 \pm 0,72)$, навпаки, нижчою $(0,04)$, ніж у хворих 3 
Огляди літератури, оригінальні дослідження, погляд на проблему, ювілеї

негативним статусом куріння на час дослідження (відповідно 44,3 [31,0; 59,0] \%; 0,44 [0,29; 0,59]; $2,22 \pm 0,45)$. Цей факт наводить на думку, що хворі із нікотиновою залежністю, на жаль, відмовляються від куріння лише при різко обмеженій функції зовнішнього дихання, оскільки в досліджуваній групі хворих з ОФВ 1 < 30 \% від належного не було жодного активного курця. Кореляційний зв'язок рівня hsСРБ із частотою загострень ХОЗЛ ( $r=+0,691$, $\mathrm{p}=0,003)$ та рівнем ОФВ $(r=-0,713, \mathrm{p}=0,002)$ був виявлений лише у хворих на ХОЗЛ з АГ, які не курили.

У свою чергу, рівень hsСРБ у коморбідних хворих корелює із зменшенням співвідношення ОФВ $/$ /ФЖЕЛ ( $r=-0,463, p=0,003)$ і функціонального респіраторного резерву, а саме, показника задишки за mMRS ( $r=+0,443, p=0,005)$. Зниження вищеозначених показників характерне для респіраторних порушень, пов'язаних із розвитком емфіземи. Гіперпродукція легеневими макрофагами, фібробластами доімунних цитокінів викликає персистування локального запалення з активацією протеолітичних процесів і розвитком емфізематозного ремоделювання легень [11]. Таким чином, сироватковий hsСРБ потенціально можна розглядати як біомаркер розвитку емфіземи, але це потребує продовження досліджень.

Рівень hsCРБ та тромбочитарна активність

В обстежених I гр. кількість тромбоцитів $(255,5[228,0 ; 282,0]$ x 10\%/л) та ступінь їх адгезивної активності $(42,0[36,0 ; 52,0] \%)$ були вищими, ніж у пацієнтів II гр. $(219,0[210,0 ; 270,0]$ x 109/л та $37,0[30,0 ; 40,0] \%,(p=0,025, p=0,030$ відповідно). Ступінь адгезії Тр у коморбідних хворих зростав із підвищенням рівня нікотинової залежності $(r=0,378, p=0,036)$.

При дослідженні стимульованої Агр Тр в обстежених I гр. виявлено перевищення швидкості АДФіндукованої Агр (46,0 [37,2; 60,0] \%/хв), тромбін-індукованого ступеня Агр $(71,05[61,9 ; 82,0] \%)$ та тромбін-індукованої активності Тр vWF (190,6 [175,4; $205,2] \%)$, порівняно з аналогічними показниками пацієнтів II гр. (відповідно: 37,4 [25,8; 46,2] \%/хв, 61,5 $[52,6 ; 71,4] \%$ та $177,0[163,4 ; 193,8] \%)$.

При підвищенні рівня hsСРБ в групі АГ зростали колаген-індукований ступінь Агр ( $r=+0,627$, $\mathrm{p}=0,038)$ та швидкість колаген-індукованої Агр ( $r=+0,556, p=0,049)$. Протилежна картина була виявлена в групі коморбідних хворих, в яких рівень hsСРБ мав негативний кореляційний зв'язок із швидкістю колаген- та тромбін-індукованої Агр ( $r=-0,516, p=0,004 ; r=-0,401, p=0,031)$. Частота загост- рень ХОЗЛ негативно корелювала із показниками тромбін-індукованих ступеня Агр ( $r=-0,449, p=0,013)$, Tp vWF ( $r=-0,429, p=0,017)$ та з АДФ-індукованою швидкістю Агр Тр $(r=-0,355, p=0,05)$, як і рівень задишки за mMRS ( $r=-0,413, p=0,023)$. Водночас, із підвищенням hsCPБ у хворих із поєднаною патологією зростав і рівень іншого гострофазового білка - фібриногену ( $r=+0,607, p=0,009)$. При зменшенні ОФВ $\mathrm{p}=0,001)$. У хворих з АГ зв'язків рівнів һsСРБ та ФГ виявлено не було. Зменшення Агр активності Тр при підвищенні рівня hsСРБ не супроводжувалося зменшенням ступеня адгезії Тр. Зменшення індукованої Агр активності Тр у хворих із поєднанням ХОЗЛ і АГ, найімовірніше, пов'язане із системним впливом глюкокортикостероїдних препаратів, а також з певною «екранізацією» від індукторів (колагену, тромбіну) тромбоцитарних рецепторів розчиненими в досліджуваній плазмі СРБ та фібриногеном

Висновки. 1. У хворих з коморбідністю ХОЗЛ та АГ обструктивні порушення зовнішнього дихання та зменшення функціонального респіраторного резерву сприяють підвищенню проявів системного запалення, що виявляється підвищенням рівнів hsСРБ та ФГ.

2. Загальний протромботичний потенціал у стабільних хворих з коморбідністю ХОЗЛ та АГ вищий, ніж у хворих з ізольованою АГ, що обумовлено як більш високою адгезивно-агрегаційною активністю Тр, незалежно від зменшення показників індукованої Агр Тр внаслідок системного впливу протизапальних препаратів, так і зростанням фібриногенемії із збільшенням проявів системного запалення.

3. У хворих на АГ підвищення рівня hsСРБ пов'язано із факторами серцево-судинного ризику: збільшенням IMT, дисліпідемією, залежністю від куріння.

4. Підвищення рівня hsСРБ у хворих на АГ сприяє тромбоцитарній активації, насамперед їх колаген-індукованій агрегації.

5. Підвищення рівнів hsСРБ, ФГ, як маркерів персистуючого системного запалення, та показників Тр активності в хворих з коморбідністю ХОЗЛ та АГ, сприяє ризику виникнення серйозних кардіоваскулярних подій не тільки при загостренні захворювань, а й у стабільний період. Це зумовлює необхідність наполегливої корекції як традиційних факторів серцево-судинного ризику, так і респіраторних проявів ХОЗЛ. 
Огляди літератури, оригінальні дослідження, погляд на проблему, ювілеї

\section{ЛІТЕРАТУРА}

1. Global Initiative for Chronic Obstructive Lung Disease (GOLD) The Global Strategy for tre Diagnosis, Management, and Prevention of Chronic Obstructive Pulmonary Disease (2018 report) http://www.goldcopd.org

2. Risk of cardiovascular comorbidity in patients with chronic obstructive pulmonary disease: a systematic review and meta-analysis / W. Chen, J. Thomas, M. Sadatsafavi, JM. FitzGerald // Lancet Respir. Med. - 2015. Vol. 3, No. 8. - P. 631-639

3. Chronic obstructive pulmonary diseases and comorbidities / M. Dercamer, W.Yanssen // Lancet Respir. Med. - 2013. - Vol. 1 - P. 73-78.

4. Assessment of cardiovascular comorbidity / J. M. Maclay, W. MacNee // Eur. Respir. Monogr. - 2013. - Vol. 59. P. 28-49.

5. Gimbrone M. Endothelial cell dysfunction and the pathobiology of atherosclerosis / M. Gimbrone, G. García-Cardeña // Circulation Research. - 2016. - Vol. 118. - P. 620-636.

6. Cell adhesion mechanisms in pletelets / D. VargaSzabo, I. Pleines, B. Nieswandt // Arteriosclerosis, Throm-

\section{REFERENCES}

1. Global Initiative for Chronic Obstructive Lung Disease (GOLD) The Global Strategy for tre Diagnosis, Management, and Prevention of Chronic Obstructive Pulmonary Disease (2018 report). Retrieved from: http://www. goldcopd.org

2. Chen, W., Thomas, J., Sadatsafavi, S., \& FitzGerald, J.M. (2015). Risk of cardiovascular comorbidity in patients with chronic obstructive pulmonary disease: a systematic review and meta-analysis. Lancet Respir. Med., 3 (8), 631-639.

3. Dercamer, M., \& Yanssen, W. (2013). Chronic obstructive pulmonary diseases and comorbidities. Lancet Respir. Med., 1, 73-78.

4. Maclay, J.M., \& MacNee, W. (2013). Assessment of cardiovascular comorbidity. Eur. Respir. Monogr., 59, 28-49.

5. Gimbrone, M., \& García-Cardeña, G. (2016). Endothelial cell dysfunction and the pathobiology of atherosclerosis. Circulation Research, 118, 620-636.

6. Varga-Szabo, D., Pleines, I., \& Nieswandt B. (2008). Cell adhesion mechanisms in pletelets. Arteriosclerosis, Thrombosis and Vascular Biology, 28, 403-412. bosis, and Vascular Biology. - 2008. - Vol. 28. - P. 403-412.

7. До питання поліморбідності та коморбідності у хворих на ХОЗЛ / М. М. Островський, П. Р. Герич // Укр. пульмонол. жур. - 2011. - Т. 4. - С. 19-24.

8. COPD: inflammatory mechanisms and systemic consequences / P. J. Barnes // J. Allergy Clin. Immunol. 2016. - Vol. 138 (1). - P. 16-27.

9. C-reactive protein as a predictor of prognosis in chronic obstructive pulmonary disease / M. Dahi, J. Vestbo, P. Lange [et al.] // Am. J. Respir. Crit. Care Med. - 2007. Vol. 175. - P. 250-255.

10. High-sensitivity C-reactive protein and cardiovascular disease / Omair Yousuf, Bibhu D. Mohanty, S. S. Martin [et al.] // JACC. - 2013. - Vol. 62 (5). - P. 397-408.

11. Родионова В. В. Актуальность проблемы хронических обструктивных заболеваний легких в структуре профзаболеваний. Критерии диагностики и экспертизы трудоспособности / В. В. Родионова // Укр. терапевт. журн. - 2006. - № 1. - С. 105-112.

7. Ostrovskyi, M.M., \& Herych, P.R. Do pytannia polimorbidnosti i komorbidnosti u patsiientiv iz KhOZL [On the issue of polymorbidity and comorbidity in patients with COPD]. Ukr. pulmonol. zhurn. - Ukrainian Pulmonological Journal, 4, 19-24. Ukrainian.

8. Barnes, P.J. (2016). COPD: inflammatory mechanisms and systemic consequences. J. Allergy Clin. Immunol., $138(1), 16-27$.

9. Dahi, M., Vestbo, J., \& Lange, P. (2013). C-reactive protein as a predictor of prognosis in chronic obstructive pulmonary disease. Am. J. Respir. Crit. Care Med., 175, 250-255.

10. Yousuf Omair, Mohanty, B.D., \& Martin, S.S. (2013). High-sensitivity C-reactive protein and cardiovascular disease. JACC, 62 (5), 397-408.

11. Rodionova, V.V. (2006). Aktualnost problem khronichnykh obstruktivnykh zabolevaniy v structure profzabolevaniy. Kriterii i ekspertizy trudosposobnosti [Actuality of the problem of chronic obstructive pulmonary diseases in the structure of occupational diseases. Criteria for diagnosis and examination of work capacity]. Ukr. terapevt. zhurn. Ukrainian Therapeutical Journal, 1, 105-112 [in Russian].

\title{
ФАКТОРИ СЕРДЕЧНО-СОСУДИСТОГО РИСКА И ПРОЯВЛЕНИЯ ПЕРСИСТИРУЮЩЕГО СИСТЕМНОГО ВОСПАЛЕНИЯ У БОЛЬНЫХ С КОМОРБИДНОСТЬЮ ХРОНИЧЕСКОЙ ОБСТРУКТИВНОЙ БОЛЕЗНИ ЛЕГКИХ И АРТЕРИАЛЬНОЙ ГИПЕРТЕНЗИИ
}

ОЕ. Н. Коваленко, В. В. Родионова

\author{
ГУ «Днепропетровская медицинская академия Министерства здравоохранения Украины»
}

РЕЗЮМЕ. Повышение уровня персистирующего системного воспаления, одним из важных биомаркеров которого является С-реактивный белок (СРБ), рассматривается как фактор, способствующий возникновению серьезных сердечно-сосудистых событий как у больных с сердечно-сосудистой патологией, так и с хронической обструктивной болезнью легких (ХОБЛ).

Цель - оценить уровень сывороточного ультрачувствительного С-реактивного белка (hsСРБ) и его связь с факторами сердечно-сосудистого риска, активностью тромбоцитов у больных с коморбидностью ХОБЛ и артериальной гипертензии (АГ). 
Огляди літератури, оригінальні дослідження, погляд на проблему, ювілеї

Материал и методы. В исследование вошли 84 пациента в стабильном состоянии, I гр. составили 44 больных ХОБЛ в сочетании с АГ І-ІІ ст., ІІ гр. - 40 больных с АГ І-ІІ ст. Проведены оценка клинико-анамнестических данных, определение офисного артериального давления (АД), индекса массы тела (ИМТ), статуса курения и степени никотиновой зависимости (Fagerstrom Test for Nicotine Dependence - FTND), ультрачувствительное определение концентрации сывороточного hsСРБ (ИФА), липидного профиля, степени адгезии, индуцированной агрегации тромбоцитов (Тр) и фибриногена (ФГ), в I гр. - оценка одышки по mMRS, частоты обострений в течение года, спирография.

Результаты. Уровень һSСРБ в I гр. был независим от возраста, ИМТ, статуса курения, липидного профиля, но

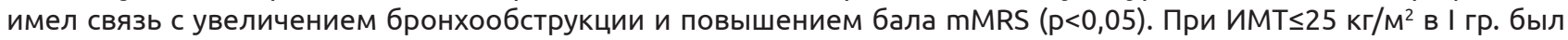
выше, чем во II гр. (P = 0,007). Вo II гр. hsСРБ выше при ИМТ $>25 \mathrm{kr} / \mathrm{M}^{2}$, чем при ИМТ $\leq 25 \mathrm{kr} / \mathrm{M}^{2}(0,008)$, у курильщиков $(0,016)$ был связан с дислипидемией $(p<0,05)$. Индуцированная коллагеном, тромбином агрегация (Агр) в I гр. имела обратную связь, во II гр. индуцированная коллагеном Агр - прямую корреляционную связь c hsCPБ (р<0,05), но общая адгезивная и индуцированная Агр активность Тр в I гр. была выше, чем во ІІ гр. В I гр. уровень ФГ имел прямую корреляционную связь с hsСРБ и обратную - с ОФВ . $^{\circ}$

Выводы. Повышение уровня һSСРБ и ФГ у стабильных больных ХОБЛ, сочетанной с АГ, связано с респираторными нарушениям. При АГ - ҺऽСРБ увеличивается при увеличении ИМТ, дислипидемии, зависимости от курения. Общий протромботический потенциал у больных I гр. выше, чем во II гр., что обусловлено повышением адгезивно-агрегационной активности ТP, а также ростом фибриногенемии с увеличением уровня hsCРБ. Повышение уровней hsСРБ, ФГ и Тр активности у коморбидных больных с ХОБЛ и АГ способствует риску серьезных кардиоваскулярных событий даже при отсутсвии обострений.

КЛЮЧЕВЫЕ СЛОВА: ХОБЛ; артериальная гипертензия; системное воспаление; высокочувствительный С-реактивний белок; факторы сердечно-сосудистого риска; тромбоцитарная активность.

\title{
CARDIOVASCULAR RISK FACTORS AND MANIFESTATION OF PERSISTENT SYSTEMIC INFLAMMATION IN PATIENTS WITH COMORBIDITY OF CHRONIC OBSTRUCTIVE PULMONARY DISEASE AND HYPERTENSION
}

\author{
@O. M. Kovalenko, V. V. Rodionova \\ Dnipropetrovsk Medical Academy, Dnipro
}

SUMMARY. An increase of the level of persistent systemic inflammation, one of the important biomarkers of which is the C-reactive protein (CRP), is considered as a factor contributing to the occurrence of serious cardiovascular events in patients with cardiovascular pathology and in patients with chronic obstructive pulmonary disease (COPD).

The aim of the study - to determine the level of serum ultra-sensitive C-reactive protein (hsCRP), its connection with cardiovascular risk factors, activity of platelets $(\mathrm{Pl})$ in patients with comorbidity COPD and arterial hypertension (AH).

Material and Methods. The study included 84 patients in a stable condition. The group I - 44 patients with COPD in combination with AH stage I-II, the group II - 40 patients with $\mathrm{H}$ stage I - II. The following indicators were determined: office blood pressure (BP), body mass index (BMI), smoking status and assessment of the degree of nicotine dependence (Fagerstrom Test for Nicotine Dependence - FTND); it was determined the high sensitivity of serum C-reactive protein concentration (hsCRP) by IFA-test, lipid profile, adhesion, induced aggregation (Agr) of thrombocytes (Pl) and fibrinogen (FG); in the group I, there was an assessment of dyspnea by mMRS, frequency of exacerbations during the year, spirography.

Results. Level of hsCRP in the group I was irrespective of age, BMI, smoking status, lipid profile, but was associated with an increase in wheeze and mMRS level $(p<0.05)$. At BMI $\leq 25 \mathrm{~kg} / \mathrm{m}^{2}$ in the group I it was higher than in the group II ( $p=0.007)$, in the group II hsCRP was higher at BMl>25 kg/m² than at BMI $\leq 25 \mathrm{~kg} / \mathrm{m}^{2}(0.008)$ in smokers (0.016) and was associated with dyslipidemia $(p<0.05)$. Induced by collagen, thrombin Pl Agr in the group I it had a reverse correlation with hsCRP, in the group II, induced by collagen PI Agr it had a direct correlation with hsCRP ( $p<0.05)$, but the total adhesion and aggregation activity of Pl in the group I was higher than in the group II. In the group I the level of FG had a direct correlation with hsCRP and the reverse one with FEV . $_{\text {. }}$

Conclusions. Increase the levels of hsSRP and FG in stable COPD patients with combined AH is associated with respiratory disorders. In patients with AH - hsSRB increases with an increase in BMI, dyslipidemia, dependence on smoking. The general prothrombotic potential in patients of the group I higher than in the group II, which is due to an increase in the adhesive-aggregation activity of TP, as well as an increase in fibrinogenemia with an increase in the level of hsSRB. Increased levels of hsSRB, FG and Pl activity in comorbid patients with COPD and AH contribute to the risk of serious cardiovascular events even in the absence of exacerbations.

KEY WORDS: chronic obstructive pulmonary disease; hypertension; systemic inflammation C-reactive protein; cardiovascular risk factors; thrombocytic activity. 